\title{
CHOLINERGIC PROPERTIES OF DESIPRAMINE AND AMOXAPINE: ASSESSMENT USING A THERMOREGULATION PARADIGM
}

\author{
STEVEN C. DILSAVER, ROBIN DAVIDSON \\ Mental Health Research Institute, Department of Psychlatry, \\ University of Michigan, Ann Arbor, Michigan, U.S.A.
}

(Final form, April 1987)

\begin{abstract}
D1Isaver, Steven $G$. and Robin Davidson: Cholinergic properties of desipramine and amoxapine: assessment using a thermoregulation paradigm. Prog. Neuro-Psychopharmaco1. \& Bio1. Psychiat, 1987, 11: 581-599.

1. The withdrawal of tricyclic antidepressants (TCAs) produces symptoms suggesting cholinergic rebound.

2. Amitriptyline (AMI), the most potent antimuscarinic agent among this class of drugs, produces supersensitivity to the muscarinic agonist, oxotremorine.

3. Enhancement of the sensitivity of cholinoceptive neurons to acetylcholine as a consequence of treatment with TCAs would account for many of the symptoms following the withdrawal of these drugs.

4. Desipramine (DMI) is the least potent antimuscarinic compound among the TCAs, yet its withdrawal produces withdrawal symptoms.

5. Recently, it was reported that amoxapine (AMX) weakly binds to muscarinic acetylcholine receptors (mAchR) in vitro. This may indicate that this drug lacks the effects antimuscarinic effects in vivo, and that it will not supersensitize cholinergic networks.

6. A thermoregulation paradigm was used to assess the sensitivity of a central muscarinic mechanism to oxotremorine before and after treatment with DMI and AMX. Treatment with either drug increased the hypothermic response to this agonist.

7. Mechanisms whereby drugs can produce cholinergic system supersensitivity, and the use of thermoregulation paradigms in assessing the properties of therapeutic agents is discussed.
\end{abstract}

Keywords: Amitriptyline, amoxapine, cholinergic, desipramine, thermoregulation paradigm

Abbreviations: amitriptyline (AMI); amoxapine (AMOX); desipramine (DMI); muscarinic acetylcholine receptor (mAchR); quinuclidnyl benzilate (QNB); tricyclic antidepressants (TCAs)

\section{Introduction}

All tricyclic antidepressants (TCAs) antagonize muscarinic cholinergic systems. The evidence for this includes the capacity of TCAs to block biochemical and physiological effects of acetylcholine (Atkinson and Landinsky, 1972; Blackwell et al., 1978; Richelson and Dininetz-Romero, 1977; Szabadi et al., 1980), the specific high affinity binding of these agents to the muscarinic acetylcholine receptor (mAchR) (Snyder and Yamamura, 1977) and their propensity to produce antimuscarinic side-effects. Drugs 
with these properties produce mAchR up-regulation (Ben-Barak and Dudai, 1980; Ehlert et a1., 1983; Wise et al., 1980; Yamada et a1., 1983) and supersensitivity of cholinoceptive neurons to acetylcholine or cholinomimetic agents (Dilsaver, 1986a,b; Friedman et al., 1969; Jaffe and Sharpless, 1968) Observations that the withdrawal of TCAs can result in symptoms which are also produced by muscarinic agonists and anticholinesterases (Dilsaver and Greden, 1984a,b; Dilsaver et a1., 1983a,b; D11saver et al., in press) is consistent with this.

Temperature is subject to regulation by a hypothalamic muscarinic mechanism (Lomax et a1., 1969) which is subject to supersensitization by chronic treatment with antimuscarinic agents and subsensitization by the protracted administration of an anticholinesterase (Overstreet et a1., 1973). This suggests TCAs may produce supersensitivity to muscarinic agonists and presents a strategy for assessing the capacities of psychotropics to modify the sensitivity of a central cholinergic mechanism(s) (Dilsaver, 1986a). We demonstrated this by treating rats with amitriptyline (AMI) $10 \mathrm{mg} / \mathrm{kg}$ intraperitoneally (ip) twice daily. This regime resulted in marked enhancement of sensitivity to the hypothermic effects of oxotremorine (Dilsaver et al., in press a). Treatment with AMI, $10 \mathrm{mg} / \mathrm{kg}$ ip twice dally for 26 days and $20 \mathrm{mg} / \mathrm{kg}$ ip twice daily for an additional 5 days produced a 20-fold increase in the sensitivity to oxotremorine. Supersensitization was also demonstrated by varying the dose of AMI and holding the dose of oxotremorine constant at $1 \mathrm{mg} / \mathrm{kg} \mathrm{ip}$ (Dilsaver and Snider, 1986). The higher the dose of AMI administered the greater the hypothermic response.

The study reported in this article was designed to assess the capacities of the least potent antimuscarinic agent among the TCAs, desipramine (DMI), and the dibenzoxazepine derivative, amoxapine (AMX), to produce supersensitivity of a central muscarinic mechanism. AMX weakly displaces the mAchR antagonist, quinuclidinyl benzilate (QNB) (Coupet et al., 1985) in vitro. This implies that it may only minimally antagonize muscarinic cholinergic systems. However, arugs can produce supersensitivity of cholinergic systems without directly blocking the mAchR. Agents activating systems which inhibit the release of acetylcholine through actions on the presynaptic cholinergic neuron are among these (Dilsaver, in press). For instance, activation of dopaminergic neurons (Ehlert et al., 1981a) and treatment with isoproterenol (Nomura et al., 1982a) can increase the density of mAchRs in the striatum and myocardium of rats, respectively. AMX inhibits the uptake of norepinephrine and its withdrawal is associated with atropine-responsive symptoms suggesting cholinergic rebound (Dilsaver et al., 1983a). Thus, its effects on muscarinic mechanisms in vivo are of interest. 
Methods

Temperature Measurement

Model VM Mini-Mitters (Mini-Mitter Co. Sun River OR) were implanted into the peritoneal cavity of adult male Sprague-Dawley rats. These devices emit Hertzian waves at a rate directly proportional to temperature. A transistor radio set to an AM frequency served as a receiver. Time to emit 10 sounds was measured using a digital display stopwatch. This measurement was then converted to temperature using a linear regression equation which was derived by measuring the emission rate of the thermosensors at three temperatures in a temperature controlled waterbath. These instruments can be sensitive to a change in temperature of $0.1^{\circ} \mathrm{C}$ (Tocco-Bradley et a1., 1985).

\section{Oxotremorine Challenge}

A11 oxotremorine challenges were conducted between 1000 and 1100 hours and were preceded by the administration of methylscopolamine nitrate, $1 \mathrm{mg} / \mathrm{kg}$ ip to block the peripheral effects of the muscarinic agonist. Baseline temperature (i.e., time to emit 10 discrete sounds) was measured 30 minutes later. Oxotremorine (base), $1 \mathrm{mg} / \mathrm{kg}$ ip was then administered and temperature recorded every 10 minutes for 120 minutes.

Table 1 outlines steps in the preparation of Mini-Mitters, the recording of raw data, the conrersion of these data to absolute core temperature and change in temperature relative to the pretreatment thermic response to oxotremorine.

\section{Pharmaceuticals}

DMI was purchased from Sigma Chemical Company (St. Louis, MO) and administered in the form of the hydrochloride. The regime of $10 \mathrm{mg} / \mathrm{kg}$ twice daily was based upon reports by Nomura et al. (1982b,1983) that it produces up-regulation of the mAchR and supersensitivity to acetylcholine in rat myocardium. AMX hydrochloride was provided as a gift by Lederle. The dose of $\mathrm{AMX}$ (molecular welght $=313.8$ ) we selected presented the advantage of being essentially equimolar to the dose of DMI (molecular weight $=302.8)$ we used. Doses of DMI and AMX both refer to the salt form. Animals

This study involved two samples of Sprague-Dawley rats, one of which received treatment with AMX (mean weight \pm SEM $=307 \pm 22.2$ grams) and the other DMI (mean weight \pm SEM $=316 \pm 30.2$ grams).

Experimental Design

The experimental design is illustrated in Figure 1. The experiment involved three phases. Phase I began with the implantation of the thermosensors and concluded after the animals had five days to recover from surgery. The first oxotremorine challenge marked the end of Phase $I$ and beginning of Phase II. This challenge provided a baseline against which all subsequent data obtained in oxotremorine challenges was to be evaluated. During Phase II all animals were treated with either AMX or DMI 10 
Table 1

Data Collection

Step 1: The Model VM Mini-Mitter is calibrated, by allowing it to come into equilibrium in a temperature controlled water bath, and measuring the rate at which it emits sounds detectable with an AM receiver at three (3) temperatures.

Step 2: The device is implanted into the peritoneal cavity and the animals are allowed 5 or more days to recover.

Step 3: The baseline (preantidepressant treatment) hypothermic response to oxotremorine (base) $1 \mathrm{mg} / \mathrm{kg}$, intraperitoneally is measured. The data sheet is organized as follows:

30 min. Post

injection

Animal of methyl-

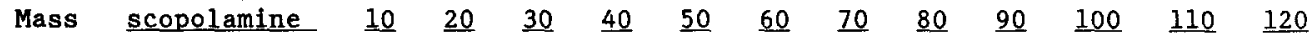

Time in seconds to emit 10 sounds

$\begin{array}{llllllllllll}3.9 & 3.81 & 3.80 & 3.30 & 3.42 & 3.30 & 3.42 & 3.45 & 3.42 & 3.6 & 3.7 & \frac{120}{3.75}\end{array}$

$$
4.00
$$

2

3

4

5

6

7

Step 4: These time measurements are used to calculate core temperature and change in core temperature relative to the baseline for a particular day. The baseline for a given day is defined by the core temperature 30 minutes after the injection of methylscopolamine (i.e., immediately prior to the injection of oxotremorine).

Step 5: $\triangle$ Time (Time to emit 10 sounds in seconds at each time point) - (time to emit 10 sounds 30 minutes after the injection of methylscopolamine) is recorded.

Animal

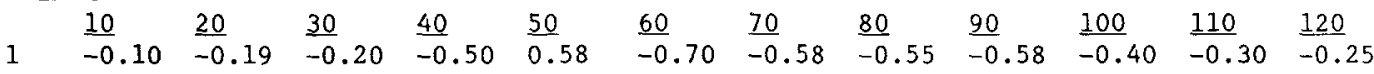

2

3

4

5

6

Step 6: $\Delta$ Time is then converted to $\Delta$ Temperature using the linear regression equation for the particular Mini-Mitter.

e.g. $y=4.5 x-50.4$

where $y=$ core temperature $\left({ }^{\circ} \mathrm{C}\right)$ and $x=$ time to emit 10 sounds 
$\Delta$ Temperature

\begin{tabular}{|c|c|c|c|c|c|c|c|c|c|c|c|c|}
\hline & & & & & & & & & & & & \\
\hline & 10 & $\underline{20}$ & $\underline{30}$ & $\underline{40}$ & $\underline{50}$ & $\underline{60}$ & $\underline{70}$ & $\underline{80}$ & 90 & 100 & 110 & 120 \\
\hline 1 & -0.46 & -0.87 & -0.92 & -2.30 & 2.67 & -3.22 & -2.30 & -2.53 & -2.3 & -1.84 & -1.38 & -1.15 \\
\hline
\end{tabular}

PHASE I PHASE II

PHASE III

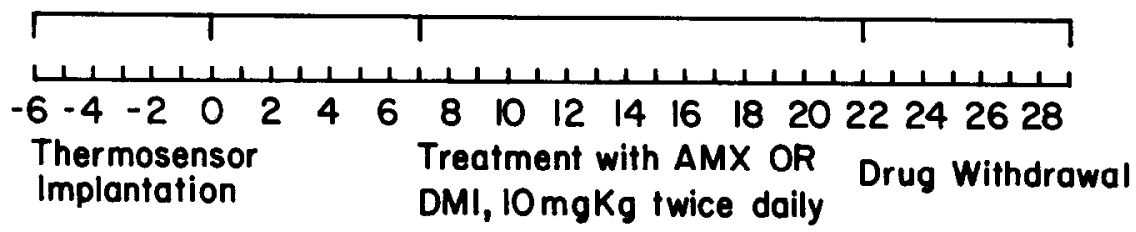

\section{Oxotremorine
Challenge}

1

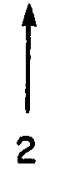

2

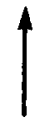

3
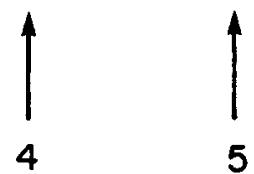

5

Fig. 1. This study is divided into three phases. Phase I is a period of preparation during which the Model VM Mini-Mitter is implanted into the peritoneal cavity and the animals allowed 5 days for recovery. Phase II begins with the first of 5 oxotremorine challenges. This provides the baseline against which all data obtained in all subsequent challenges is evaluated. Treatment with either AMX or DMI (10 $\mathrm{mg} / \mathrm{kg} \mathrm{ip}$ twice daily) is started at the conclusion of this challenge. The animals challenged with oxotremorine at 7 day intervals. All oxotremorine challenges follow the preceding dose of antidepressant by 17-18 hours. Challenge data entering into statistical analyses for the treatment phase is that obtained at the end of the third week of antidepressant administration or available from the challenge immediately preceding a loss of the animal from the study due to thermosensor failure or death. Phase III is a period of drug withdrawal.

$\mathrm{mg} / \mathrm{kg}$ ip twice daily (at 0900 and 1700). At seven day intervals, 17-18 hours after the last dose of the antidepressant, oxotremorine challenges were repeated. This continued for three weeks. The data used in the analyses reported here were obtained at the time of the fourth oxotremorine challenge (i.e., at the conclusion of the three week period of antidepressant treatment) or at the point at which animals were lost to the study due to thermosensor failure $(n=1)$ or in the case of one animal death. Phase III was a period of drug withdrawal. During this phase the animals were left undisturbed and untreated so that we could assess whether the effects of 
antidepressant treatment were detectable one week after its discontinuation. Table 1 sumarizes steps in the use of Mini-Mitters and in the process of data collection. Statistical Analysis

The proportion of animals in which the hypothermic response was significantly enhanced following antidepressant treatment (a dichotomous variable with a binomial distribution), change in temperature with respect to time (i.e., significance of the mean difference) for each individual animal, the mean and mean maximum hypothermic response of the sample, and change in hypothermic response at each of the 12 time points for each sample relative to baseline (i.e., the pretreatment phase) were designated as dependent variables. Dichotomous data were assessed by applying the binomial theorem (Lipschut2, 1965; Siege1, 1956) to calculate the probability that in a given number of observations, "k", " $n$ " outcomes would be observed where the probability of observing " $n$ " by chance ( $\alpha$, the probability of a type I error) is known. The theorem allows the calculation of the probability of observing a given number of statistically significant outcomes in a given number of applications of a statistical test.

Mean change in the hypothermic response for each animal was calculated by subtracting the hypothermic response prior to treatment with DMI or AMX from the response after treatment at all of the 12 time points and averaging these. The significance of the mean for these paired differences for individual animals were assessed using Student's paired t-test. The maximum change in hypothermic response was assessed by pairing the maximum hypothermic response of each animal in the sample before treatment with its maximum response after treatment. The mean thermic response of the sample was assessed by pairing the mean thermic response of each of the animals before treatment with that at the end of treatment and after 7 days of abstinence by applying the paired t-test. All measures of variance in the results section refer to the standard deviation of the mean difference between matched pairs (Sd) (Goldstein, 1964).

\section{Results}

DMI. Table 2 summarizes data on the response of individual animals ( $n=8$ ) to oxotremorine after treatment with DMI relative to their pretreatment baseline. Four (4) of 8 rats exhibited enhanced sensitivity to oxotremorine at the 0.01 level or less following treatment with DMI ( $p=1.7 \times 10^{-10}$, binomial test) (Segel, 1956). The difference in the mean $\left(\bar{X} \pm S_{d}=0.86 \pm 0.27, t=3.19,6 \mathrm{df}, \mathrm{p}<0.02\right)$ and mean $\operatorname{maximum}\left(\overline{\mathrm{X}} \pm \mathrm{S}_{\mathrm{d}}=1.19 \pm 0.47, \mathrm{t}=2.53,7 \mathrm{df}, \mathrm{p}<0.05\right)$ hypothermic responses were significant. After 7.5 days of abstinence the sample no longer exhlbited supersensitivity to the hypothermic effect of oxotremorine. However, two of 6 animals continued to demonstrate supersensitivity to the thermic effects of oxotremorine at 
Table 2

Summary of Statistical Analysis of Data Collection on Animals Treated with Desipramine (DMI)

\begin{tabular}{|c|c|c|c|c|c|c|}
\hline $\begin{array}{l}\text { Animal } \\
\text { Number }\end{array}$ & $\begin{array}{l}\text { Days of } \\
\text { Treatment } \\
\text { When Last } \\
\text { Challenged with } \\
\text { Oxotremorine }\end{array}$ & $\begin{array}{l}\text { Reason for Early } \\
\text { Discontinuation } \\
\text { from Study }\end{array}$ & $\begin{array}{l}\quad \text { Mean } \\
\text { Hypothermic } \\
\text { Response }\end{array}$ & $\mathrm{DF}^{\mathrm{b}}$ & $t^{c}$ & $\mathrm{p}^{\mathrm{d}}$ \\
\hline 1 & 21 & - & -1.18 & 11 & -5.9 & $<0.001$ \\
\hline 2 & 21 & - & -1.50 & 11 & -5.12 & $<0.001$ \\
\hline 3 & 21 & - & +0.32 & 11 & +2.00 & n.s. \\
\hline 4 & 21 & - & +0.13 & 11 & +0.46 & n.s. \\
\hline 5 & 21 & - & -0.54 & 11 & -1.8 & n.s. \\
\hline 6 & 21 & - & -.08 & 11 & -.16 & n.s. \\
\hline 7 & 14 & Mini-Mitter failure & -1.28 & 11 & -3.76 & $<0.01$ \\
\hline \multirow[t]{10}{*}{8} & 7 & $\begin{array}{l}\text { Died } 10-20 \text { minutes } \\
\text { after oxotremorine } \\
\text { injection following } \\
14 \text { days of treatmen }\end{array}$ & -0.98 & 11 & -4.26 & $<0.01$ \\
\hline & & \multicolumn{2}{|c|}{$\bar{X}+\operatorname{SEM}=-0.64$} & 0.24 & -2.67 & $<0.05 \mathrm{e}$ \\
\hline & & \multicolumn{2}{|c|}{$\begin{array}{l}\text { Mean Hypothermic Response } 7 \text { days } \\
\text { after the last dose of DMI } \\
\text { relative to the pre-treatment } \\
\text { baseline }\end{array}$} & $\mathrm{DF}^{\mathrm{b}}$ & $t^{c}$ & $\mathrm{p}^{\mathrm{d}}$ \\
\hline & & \multicolumn{2}{|c|}{-0.87} & 11 & -4.35 & $<0.01$ \\
\hline & & \multicolumn{2}{|c|}{-1.54} & 11 & -6.16 & $<0.001$ \\
\hline & & \multicolumn{2}{|c|}{+2.34} & 11 & +9.75 & $<0.001^{f}$ \\
\hline & & \multicolumn{2}{|c|}{+0.39} & 11 & +3.25 & $<0.01^{\mathrm{f}}$ \\
\hline & & \multicolumn{2}{|c|}{+1.03} & 11 & +6.06 & $<0.001^{\mathrm{f}}$ \\
\hline & & \multicolumn{2}{|c|}{-0.03} & 11 & -0.23 & n.s. \\
\hline & & \multicolumn{2}{|c|}{$\vec{X}+\operatorname{SEM}=+0.09 \pm 0.57$} & 5 & +0.16 & n.s. \\
\hline
\end{tabular}

The probability that 4 or more of 8 animals would exhibit supersensitive responses to oxotremorine is $6.7 \times 10^{-7}$.

(a) This mean was calculated by pairing the absolute value of the hypothermic response to oxotremorine at each of the 12 time points $(10,20,30 \ldots 120$ minutes) after the injection of oxotremorine before and after treatment with DiII or AMX and subtracting the latter from the former, summing these differences and dividing by 12. Thus, the mean hypothermic response for a given animal $\sum$ [(absolute value of the hypothermic response before DMI or AMX $t_{10}, 20, \ldots 120$ ) - (absolute value of hypothermic response after DMI or AMX $t_{10}, 20 \ldots 120 j \mathrm{j} \div 12$

(b) DF, Degrees of Freedom $=12$ time points $-1=11$

(c) This statistic is calculated using the formula for Student's paired t-test. The measure of variance entering into the calculation is based on the standard deviation of the difference, $s_{d}$, in the hypothermic response to oxotremorine at the 12 time points before and after treatment with DMI or AMI.

(d) p values refer to the two-tailed probabilities of a type I error. 
(e) The mean in this row $=\Sigma$ [(mean hypothermic response of each individual animal before treatment with DMI of AMX) - (mean hypothermic response of each individual animal after treatment with DMI or AMX)] $\div 12$

DF = sample size -1

$t$ was calculated using the formula for Student's paired t-test.

(f) Denotes a hyperthermic response

$\alpha<0.01$ and 3 of 6 exhibited significant decreases in the hypothermic response to this drug at the 0.01 level. Thus, the animals comprising the sample demonstrated marked variability in their responses to oxotremorine at this time.

Treatment with DMI was associated with a significant increase in the hypothermic response $70(p<0.001), 80(p<0.01), 90(p<0.02), 100(p<0.02), 110(p<0.02)$ and 120 ( $p<0.001$ ) minutes after the injection of oxotremorine. The probability of 6 of 12 measurements being significant at $\alpha<0.02$ is $8.7 \times 10^{-10}$ (binomial test). Figure 2 illustrates the difference in the mean thermic response to oxotremorine across time after treatment with DMI relative to the pretreatment baseline. These data are presented with additional statistical information in Table 3 .

AMX. Table 4 summarizes data on the responses of individual animals $(n=9)$ to oxotremorine after treatment with AMX relative to their pretreatment baseline. Five of 9 animals cxhibited an cnhanced hypothermic responsc at the 0.05 level or less (p = $1.92 \times 10^{-8}$, binomial test). The mean hypothermic response ( $\mathrm{X} \pm \mathrm{S}_{\mathrm{d}}=0.56 \pm$ $\left.0.19^{\circ} \mathrm{C}, t=2.94,6 \mathrm{df}, \mathrm{p}<0.05\right)$ increased significantly. There was also a trend toward a significant increase in the maximum hypothermic response $\left(X \pm S_{d}=0.61 \pm\right.$ $0.31^{\circ} \mathrm{C}, t=1.96,8 \mathrm{df}, \mathrm{p}\langle 0.10\rangle$ to oxotremorine. Following the 7.5 day withdrawal phase, the sample did not evidence enhanced responsiveness to oxotremorine.

Treatment with AMX was associated with an increase in the hypothermic response 60 ( $\mathrm{p}$ $(0.02), 70(p<0.001), 80(p<0.01), 90(p<0.01), 100(p<0.01), 110(p<0.01)$ and 120 ( $p<0.02$ ) minutes after the injection of oxotremorine. The probability of 7 of 12 measurements being significant at $\alpha<0.02$ is $8.0 \times 10^{-12}$. Figure 3 illustrates the difference between the mean thermic response to oxotremorine across time before and after treatment with AMX. These data are presented with additional statistical information in Table 5 .

\section{Discussion}

\section{Thermoregulation Paradigm}

A thermoregulation paradigm and four dependent variables (1) the proportion of animals exhibiting a significant hypothermic responses at the level of $\alpha<0.05,(2)$ the difference in the mean hypothermic response of each individual animal over time after the injection of oxotremorine before and after antidepressant treatment, (3) the mean change and mean maximum difference in the hypothermic responses of a sample before and after DMI or AMX administration, and (4) change in the hypothermic response 


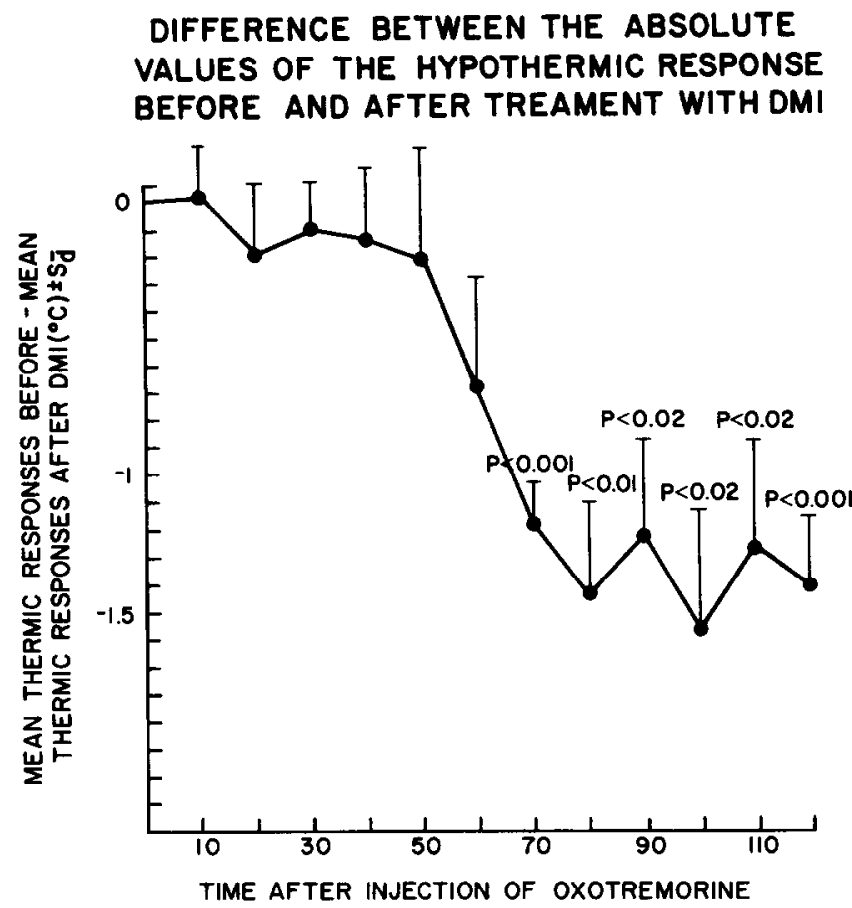

Fig. 2. Mean change in the thermic response $\pm S_{d}$ at 10 minute intervals following the injection of oxotremorine, $1 \mathrm{mg} / \mathrm{kg}$ ip in animals treated with DMI ( $\mathrm{N}=8$ ).

Table 3

Change in the Mean Thermic Response $\left({ }^{\circ} \mathrm{C}\right) \pm S_{d}$ Across Time After Treatment with Desipramine

\begin{tabular}{|c|c|c|c|c|c|}
\hline 10 minutes & $\begin{array}{l}\text { Minutes } \\
20 \text { minutes }\end{array}$ & $\begin{array}{c}\text { after the inj } \\
30 \text { minutes }\end{array}$ & $\begin{array}{c}\text { tion of oxotr } \\
40 \text { minutes }\end{array}$ & $\begin{array}{l}\text { norine } \\
50 \text { minutes }\end{array}$ & 60 minutes \\
\hline$-0.02 \pm 0.19$ & $-0.02 \pm 0.26$ & $-0.10 \pm 0.17$ & $-0.14 \pm 0.26$ & $-0.2 \pm 0.39$ & $-0.68 \pm 0.41$ \\
\hline 70 minutes & $\begin{array}{l}\text { Minutes } \\
80 \text { minutes } \\
\end{array}$ & $\begin{array}{l}\text { after the inj } \\
90 \text { minutes }\end{array}$ & $\begin{array}{c}\text { tion of oxotr } \\
100 \text { minutes }\end{array}$ & $\begin{array}{l}\text { norine } \\
110 \text { minutes }\end{array}$ & 120 minutes \\
\hline $\begin{aligned}-1.18 & \pm 0.16 \\
p & <0.001\end{aligned}$ & $\begin{array}{c}-1.43 \pm 0.32 \\
\mathrm{p}<0.01\end{array}$ & $\begin{aligned}-1.22 & \pm 0.35 \\
p & <0.02\end{aligned}$ & $\begin{aligned}-1.57 & \pm 0.45 \\
p & <0.02\end{aligned}$ & $\begin{array}{c}-1.27 \pm 0.39 \\
p<0.02\end{array}$ & $\begin{array}{c}-1.41 \pm 0.25 \\
p<0.001\end{array}$ \\
\hline
\end{tabular}

This table lists the change in the mean hypothermic response $\pm S_{d}$, relative to baseline, at each of 12 time points for animals treated with DMI. Temperature was measured every 10 minutes after the injection of oxotremorine (at $t=0)$. Probability statements are based on the results of Student's paired t-test in which the thermic responses before and after antidepressant administration were the matched pairs, and the mean difference in the absolute value of the thermic response before and after treatment constitutes the mean effect of treatment. 
Table 4

Summary of Statistical Analysis of Data Collection on Animals Treated with Amoxapine

\begin{tabular}{|c|c|c|c|c|c|c|}
\hline $\begin{array}{l}\text { Anima } 1 \\
\text { Number }\end{array}$ & $\begin{array}{l}\text { Days of } \\
\text { Treatment } \\
\text { When Last } \\
\text { Challenged with } \\
\text { Oxotremorine }\end{array}$ & $\begin{array}{l}\text { Reason for Early } \\
\text { Discontinuation } \\
\text { from Study }\end{array}$ & $\begin{array}{l}\quad \text { Mean } \\
\text { IIypothermic } \\
\text { Response }\end{array}$ & $\mathrm{DF}^{\mathrm{b}}$ & $t^{c}$ & $\mathrm{p}^{\mathrm{d}}$ \\
\hline 1 & 21 & - & -0.78 & 11 & -3.9 & $<0.01$ \\
\hline 2 & 21 & - & -1.46 & 11 & -9.13 & $<0.001$ \\
\hline 3 & 21 & - & +0.38 & 11 & +1.9 & $\mathrm{n} \cdot \mathrm{s}$ \\
\hline 4 & 21 & - & -0.82 & 11 & -4.1 & $<0.01$ \\
\hline 5 & 21 & - & -0.83 & 11 & -3.95 & $<0.01$ \\
\hline 6 & 21 & - & +0.21 & 11 & +1.05 & n.s. \\
\hline 7 & 21 & - & -0.37 & 11 & -1.00 & n.s. \\
\hline 8 & 21 & - & -1.08 & 11 & -3.96 & $<0.01$ \\
\hline \multirow[t]{13}{*}{9} & 21 & - & -0.52 & 11 & -2.36 & $<0.05$ \\
\hline & & \multicolumn{3}{|c|}{$\bar{X}+\operatorname{SEM}=-0.57 \pm 0.19$} & 2.85 & $<0.05$ \\
\hline & & \multicolumn{2}{|c|}{$\begin{array}{l}\text { Mean Hypothermic Response } 7 \text { days } \\
\text { after the last dose of DMI } \\
\text { relative to the pre-treatment } \\
\text { baseline }\end{array}$} & \multicolumn{2}{|l|}{$\mathrm{DFb}$} & $\mathrm{p}^{\mathrm{d}}$ \\
\hline & & \multicolumn{2}{|c|}{+0.82} & 11 & +1.6 & n.s. \\
\hline & & \multirow{2}{*}{\multicolumn{2}{|c|}{$\begin{array}{l}+0.28 \\
+1.19\end{array}$}} & 11 & +1.56 & n.s. \\
\hline & & & & 11 & +9.13 & $<0.001 *$ \\
\hline & & \multicolumn{2}{|c|}{-0.06} & 11 & -0.75 & n.s. \\
\hline & & \multicolumn{2}{|c|}{-0.35} & 11 & -1.46 & n.s. \\
\hline & & \multicolumn{2}{|c|}{-0.45} & 11 & -1.41 & n.s. \\
\hline & & \multirow{2}{*}{\multicolumn{2}{|c|}{$\begin{array}{l}-0.16 \\
+0.38\end{array}$}} & 11 & -0.84 & n.s. \\
\hline & & & & 11 & +2.71 & $<0.05$ \\
\hline & & \multicolumn{2}{|c|}{-0.03} & 11 & -0.25 & n.s. \\
\hline & & \multicolumn{2}{|c|}{ Mean \pm SEM $=0.18 \pm 0.17$} & 8 & +1.00 & n.s. \\
\hline
\end{tabular}

This table lists the mean difference between the absolute value of the mean hypothermic response to oxotremorine before and arter treatment with AMX. Please see the footnote to Table 2 for further details.

The probability of one or more of 9 animals exhibitng a decreased hypothermic response to oxotremorine at $\alpha<0.05=0.044$.

The probability of 6 of 9 animals exhibiting significance at $\alpha<0.05=1.11 \mathrm{x}$ $10^{-6}$.

a-e Please see the footnote to Table 1.

* This animal exhibited a significant decrease in its hypothermic response after treatment. 


\section{DIFFERENCE OF THE ABSOLUTE VALUES OF THE HYPOTHERMIC RESPONSE BEFORE AND AFTER TREATMENT WITH AMX}

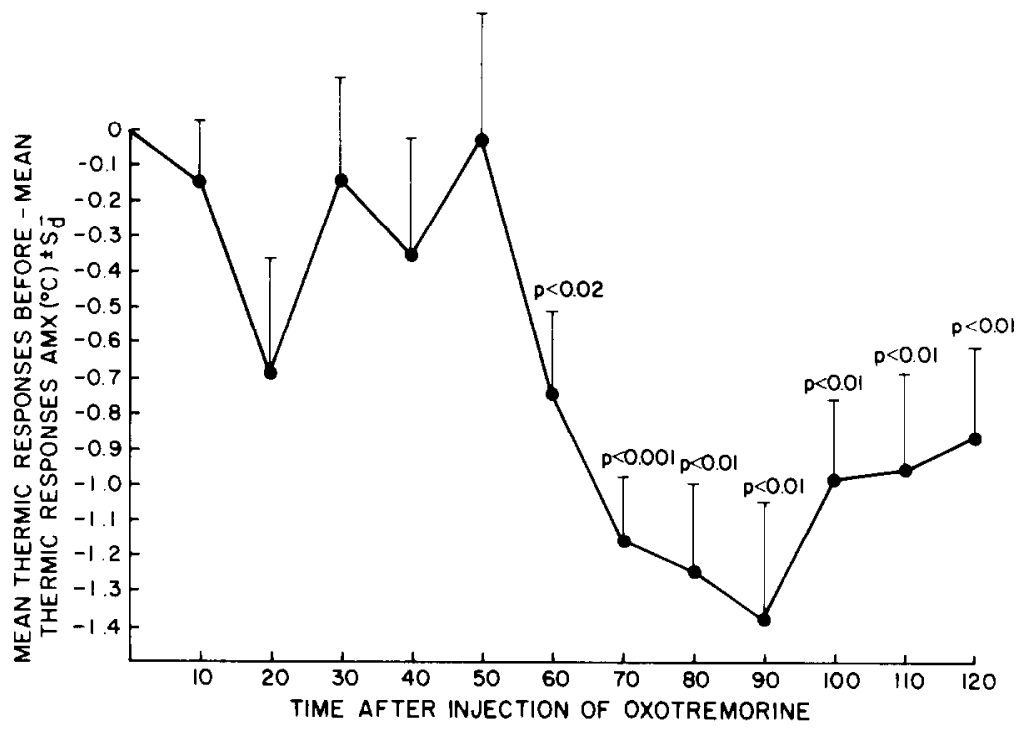

Fig. 3. Mean difference $\pm S_{d}$ between the hypothermic response to oxotremorine 1 $\mathrm{mg} / \mathrm{kg}$ at baseline (prior to treatment) and after 21 days of treatment with AMX 10 $\mathrm{mg} / \mathrm{kg}$ ip twice daily $(\mathrm{N}=9)$.

Table 5

Change in the Mean Thermic Response $\left({ }^{\circ} \mathrm{C}\right) \pm \mathrm{S}_{\mathrm{d}}$ Across Time After Treatment with Amoxapine

\begin{tabular}{|c|c|c|c|c|c|}
\hline 10 minutes & $\begin{array}{l}\text { Minute } \\
20 \text { minutes } \\
\end{array}$ & $\begin{array}{l}\text { after the inj } \\
30 \text { minutes }\end{array}$ & $\begin{array}{c}\text { ction of oxot } \\
40 \text { minutes }\end{array}$ & $\begin{array}{l}\text { norine } \\
50 \text { minutes }\end{array}$ & 60 minutes \\
\hline$-0.14 \pm 0.17$ & $\begin{array}{c}-0.68 \pm 0.32 \\
p<0.10\end{array}$ & $-1.40 \pm 0.29$ & $-0.35 \pm 0.33$ & $-0.02 \pm 0.35$ & $\begin{array}{c}-0.74 \pm 0.23 \\
p<0.02\end{array}$ \\
\hline 70 minutes & $\begin{array}{l}\text { Minut } \\
80 \text { minutes } \\
\end{array}$ & $\begin{array}{l}\text { after the inj } \\
90 \text { minutes }\end{array}$ & $\begin{array}{l}\text { tion of oxot } \\
100 \text { minutes }\end{array}$ & $\begin{array}{l}\text { norine } \\
110 \text { minutes }\end{array}$ & 120 minutes \\
\hline $\begin{array}{c}-1.16 \pm 0.18 \\
\mathrm{p}<0.10\end{array}$ & $\begin{array}{c}-1.24 \pm 0.24 \\
p<0.01\end{array}$ & $\begin{aligned}-1.38 & \pm 0.33 \\
p & <0.01\end{aligned}$ & $\begin{array}{c}-0.99 \pm 0.23 \\
p<0.01\end{array}$ & $\begin{array}{c}-0.96 \pm 0.27 \\
p<0.01\end{array}$ & $\begin{aligned}-0.87 & \pm 0.25 \\
p & <0.01\end{aligned}$ \\
\hline
\end{tabular}

This table lists the mean change in the hypothermic response $\pm S_{d}$ at each of 12 time points after the injection of oxotremorine for animals treated with AMX. For additional details please see the footnote to Table 3 . 
at each of 12 time points $(10,20,30 \ldots 120$ minutes $)$ after the administration of oxotremorine were useful in studying the influence of a TCA and a second generation antidepressant reported to minimally interact with the mAchR on a central cholinergic mechanism. Both agents produce supersensitivity of a cholinergic mechanism involved in the regulation of core temperature. This is presumably due to central muscarinic effects of these antidepressants. First, the hypothermic response to oxotremorine is not blocked by methylscopolamine, but is by scopolamine (Dilsaver et al., in press,a). Though oxotremorine may have weak nicotinic effects (Bowman and Rand, 1980) and a TCA, amitriptyline produces supersensitivity to the hypothermic effects of nicotine (Dilsaver et al., in press, Dilsaver and snider, 1986), activation of a nicotinic mechanism by oxotremorine is not a plausible explanation for the findings reported here. We demonstrated that pretreatment with mecamylamine, $2.5 \mathrm{mg} / \mathrm{kg} \mathrm{ip}$ increases the hypothermic response to oxotremorine (Dilsaver and Snider, 1986; Dilsaver et al., in press b). This suggests either that oxotremorine's weak nicotinic effects partially antagonize its muscarinic cffects or that its muscarinic effects result in a compensatory response by an endogenous nicotinic mechanism. For example, muscarinic stimulation inhibits the release of norepinephrine whereas nicotinic agonists promote the release of this neurotransmitter within the hypothalamus (Westfa11, 1973). In conclusion, these data strongly suggest that both DMI and AMX produce supersensitivity of a central muscarinic cholinergic mechanism.

\section{Mechanism of Action}

Additional data suggests that DMI produces cholinergic system supersensitivity in man and animals. Chronic treatment with DMI enhances the miotic response to pilocarpine in depressed subjects (Dilsaver and Greden, 1983; Shur et a1., 1983). Nomura et a1. (1982b; 1983) reported that treatment with DMI, $10 \mathrm{mg} / \mathrm{kg}$ ip twice daily increases the negative ionotropic effects of acetylcholine and produces an exaggerated increase in the activity of ornithine decarboxylase in response to a cholinergic agonist. The discontinuation of DMI also produces withdrawal symptoms suggestive of cholinergic overdrive (Dilsaver et al., 1983a,b; Dilsaver and Greden, 1984a,b; Dilsaver et al., in press b). AMX produces a low incidence of "antimuscarinic-like" side effects (PDR, 1986) and its discontinuation has also been associated with withdrawal symptoms which suggest cholinergic rebound (Dilsaver et al., 1983a).

Mechanisms whereby antidepressants produce up-regulation or supersensitivity of cholinergic systems can be classified according to the site of their effect. Drugs may act postsynaptically to block the mAchR or presynaptically to inhibit the release of acetylcholine (Dilsaver, in press). Classical antimuscarinic agents such as scopolamine or atropine (Ben-Barak and Dudai, 1980; Ehlert et al., 1983; Wise et a1., 1980; Yamada et al., 1983) and related compounds such as the TCAs (Goldman and Erickson, 1983; Rehavai et al., 1980; Nomura et al., 1982b, 1983) which bind with 
specificity to mAchRs all denervate cholinoceptive neurons by competitively antagonizing the action of acetylcholine at the postsynaptic sites. This results in a compensatory response involving an increased density of $\mathrm{mAch}$ radioligand binding sites and supersensitivity (Frledman et al, 1969; Jaffe and Sharpless, 1968; Sitaram et al., 1979; Gillin et al., 1979; Innes and Nickerson, 1975) to cholinergic agonists.

The second category of agents producing up-regulation and supersensitivity of muscarinic cholinergic systems is comprised of at least five classes of agents which act at the presynaptic nerve terminal to inhibit the release of acetylcholine (Dilsaver, in press). Opiate agonists (Domino and Wilson, 1973; Jhamandas et al., 1973a,b), cannabinoids (Kumbarachi and Nastuk, 1980; Layman and Milton, 1971; Yoshimura et al., 1974), barbiturates (Nordberg and Wahlstrom, 1981; Nordberg and Sundwa11, 1977; Wahlstrom and Nordberg, 1979; Wahlstrom and Ekwa11, 1976; Wahlstrom, 1978), ethanol (Rabin et al., 1980; Smith, 1983; Tabakoff et al., 1979), and certain serotinergic (ögren et al., 1985a,b), dopaminerglc (Ehlert et al., 1981) and adrenergic (Blosser, 1983) agonists are in this class. Nomura et al. (1982a), for example, reported that isoproterenol induced cholinergic system supersensitivity and up-regulation of QNB binding sites in rat myocardium. Blosser (1983) found that activation of $B$-adrenergic receptors increased the density of cholinoceptors in chick myotubes. These reports are consistent with the capacity of norepinephrine (Beani et al., 1978) to inhibit the release of acetylcholine from brain slices. Dopamine (Bluth and Langnicke, 1985b; Baud et al., 1985) and serotoninergic (Vizi et al., 1981) agonists also reduce the release of acetylcholine in the mammalian brain. Ehlert et al. (1981b) reported that dopaminergic agonists produced an increased density of mAchR binding sites in the corpus striatum of rodents. Ögren et a1. (1985a,b) reported that chronic treatment with a serotinergic agonist produced enhanced sensitivity to the tremoreginic effects of muscarinic agonists. Thus, it is conceivable that DMI or AMX could produce supersensitivity to oxotremorine by either directly blocking the postsynaptic mAchR or through an effect on the presynaptic neuron. However, Coupet et al. (1985) reported that amoxapine weakly displaces QNB in mAchR binding studies. Thus, the mechanism whereby AMX produces supersensivity to oxotremorine may indeed involve diminution in the release of acetylcholine.

These data have several theoretical implications. First, they illustrate that in vitro and in vivo studies can yield strikingly different results. The in vitro data suggest that AMX would have minimal cholinergic effects but the measure of a functional index indicates otherwise. However, seemingly contradictory in vitro and physiological data are reconcflable. AMX may act presynaptically to partially denervate postsynaptic cholinergic neurons. Secondly, Gohens and Baldessarini (1985) recently reported that tolerance sometimes develops to the antidepressant effects of TCAs. Data suggest that supersensitivity of cholinergic systems may be involved in 
the pathophysiology of affective disorders (Dilsaver, 1986a-d). Enhancement of the sensitivity of cholinergic systems by antidepressants might increase the probability of depressive relapse. Third, physiological models, such as the thermoregulation paradigm set forth in this article, can be used to evaluate new antidepressants for their capacity to modify the sensitivity of cholinergic networks. Such models could have considerable value in the pre-clinical evaluation of pharmacological agents.

\section{Conclusions}

Rats were treated with DMI $10 \mathrm{mg} / \mathrm{kg}$ ip twice daily or AMX $10 \mathrm{mg} / \mathrm{kg}$ ip twice daily for up to 21 days after the baseline thermic response to oxotremorine, $1 \mathrm{mg} / \mathrm{kg}$ ip was determined. Temperature was measured telemetrically every 10 minutes for 120 minutes after the injection of oxotremorine. Oxotremorine challenges were repeated at 7 day intervals. Both groups of animals demonstrated enhanced sensitivity to the hypothermic effects of the cholinomimetic. The thermoregulation paradigm employed in this report has now demonstrated the capacity of AMI, DMI and AMX to produce supersensitization of a central cholinergic mechanism. The paradigm is applicable to the evaluation of novel antidepressants with unknown effects on muscarinic mechanisms.

Thermoregulation paradigms are applicable to the study of an array of problems. For instance, a thermoregulation paradigm was used to demonstrate that chronic treatment with AMI enhances sensitivity to the hypothermic effects of nicotine (Dilsaver and Snider, 1986; Dilsaver et al., in press b). Methods presented in this article were also used to establish that chronic forced swim stress (Dilsaver et al., 1986b) and inescapable footshock produce supersensitivity (Dilsaver and Alessi, in press b) of a central muscarinic mechanism. Thus, a thermoregulation paradigm is useful as a means of studying the pharmacology of antidepressants, the neurobiology of chronic stress or other manipulations affecting cholinergic mechanisms. It is noteworthy that the paradigm we used generated data indicating that $A M X$, a drug which weakly interacts with the mAchR produces supersensitivity of a central muscarinic mechamism. An in vitro study would suggest otherwise. The measurement of a physiological parameter sensitive to both pre- and post-synaptic actions of a manipulation can convey information that the measurement of binding variables does not.

\section{Acknowledgements}

Please direct all correspondence and request for reprints to Dr. Dilsaver at the above address. Supported in part by Physician-Scientist Career Development Award (Muscarinic Receptor Abnormalities in Affective Illness) Grant \#SRCK11 MH00553-01. 


\section{References}

ATKINSON, J. and LANDINSKY, H. (1972) The quantitative study of the anticholinergic action of several tricyclic anti-depressants on the rat isolated fundal strip. Br. J. Pharmacol. 45: 519-524.

BAUD, P., ARBILLA, S., CANTRELL, R.C., and LANGER, S.Z. (1985) Trace amines enhibit the electrically evoked release of $\left[{ }^{3} \mathrm{H}\right]$ acetylcholine from slices of rat striatum in the presence of pargyline: similarities between B-pheneylethalamine and amphatemine. J. Pharmacol. Expt. Therap. 235: 220-299.

BEANI, L., BIANCHI, C., GIAOMELLI, A., and TAMBERI, F. (1978) Noradrenalin inhibition of acetylcholine release from guinea pig brain. Eur. J. Pharmacol. 48: 179-19.

BEN-BARAK, Y, and DUDAI, Y. (1980) Scopolamine induces an increase in muscarinic receptor level in rat hippocampus. Brain Res. 193: 309-313.

BLACKWELL, B., STEFOPOULOS, A., ENDERS, P., KUZMA, R., and ADOLPHE, A. (1978) Anticholinergic activity of two tricyclic antidepressants. Am. J. Psychiatry 135:

BLOSSER, J.C. (1983) B-adrenergic receptor activation increases acetylcholine receptor number in cultured skeletal muscle myostolses. J. Neurochem. 40: 1144-9.

BLUTH, R., LANGNICKEL, R., and OH, T. (1985) Modulation by dopaminergic and serotonergic systems of cholinergic interneurons in nucleus accumlens and striatum. Pol. J. Pharmcol. 37: 753-65.

BOWMAN, W.C. and RAND, M.J. (1980) Textbook of Pharmacology. Blackwell Scientific Publications, Oxford, 18-25 pP.

COHEN, B.M. and BALDERSARINI, R.J. (1985) Tolerance to the therapeutic effects of antidepressants. Am. J. Psychiatry 142: 489-490.

COUPET, J., FISHE, S.K., RAUGH, C.E., LAI, F. and BEER, B. (1985) Interaction of amoxapine with muscarinic cholinergic receptors: an assessment. Eur. J. Pharmcol. 112: $231-235$.

DILSAVER, S.C. (1986a) Pathophysioogy of "cholinoceptor" supersensitivity in affective disordera. Biol. Psychiatry $\underline{21}: 813.829$.

DILSAVER, S.C. (1986b) Pharmacologic induction of cholinergic system up-regulation and supersensitivity in affective disorders research. J. Clin. Psychopharmacol. 6: 65-72.

DILSAVER, S.C. (1986c) Cholinergic mechanisms in depression. Brain Research Rev. 11. $285-316$.

DILSAVER, S.C. (1986d) Cholinergic mechanisms ain affective illness: future directions for research.

DILSAVER, S.C. (in press) The pathophysiologies of substance abuse and affective disorders: an integrated mode1? J. Clin. Psychopharmacol.

DILSAVER, S.C., ALESSI, N.E. and MJCHRZAK, M.J.(in press a) Amitriptyline produces supersensitivity to the hypothermic effects of nicotine. Biological Psychiatry.

DILSAVER, S.C. and ALESSI, N.E. (in press b) Chronic inescapable footshock produces cholinergic system supersensitivity. Biological Psychiatry. 
DILSAVER, S.C. and ALESSI, N.E.. Temperature as a dependent variable in the study of cholinergic mechanisms. Brain Res., submitted.

DILSAVER, S.C. and GREDEN, J.F. (1983) Antidepressant withdrawal syndromes: evidence for supersensitivity of the cholinergic system as an etiologic factor. J. Clin. Psychopharmacol. $3: 330$.

DILSAVER, S.C., FEINGERG, M., and GREDEN, J.F. (1983a) Antidepressant withdrawal symptoms treated with anticholinergic agents. Am. J. Psychiatry 140: 249-51.

DILSAVER, S.C., KRONFOL, Z., GREDEN, J.F., and SACKELLARES, J.C. (1983b) Antidepressant withdrawal syndromes: evidence supporting the cholinergic overdrive hypothesis. J. Clin. Psychopharmacol. 3: 157-164.

DILSAVER, S.C. and GREDEN, J.F. (1984a) Antidepressant withdrawal phenomena. Biol. Psychiatry, 19: 237-256.

DILSAVER, S.C., MAJCHRZAK, M.J., ALESSI, N.E. (In press b) Chronic treatment with amitriptyline produces supersensitivity to nicotine. Biological Psychiatry.

DILSAVER, S.C. and GREDEN, J.F. (1984b) Antidepressant withdrawal syndromes: mechanism and theoretical significance. Brain Res. Rev. 7: 29-42.

DILSAVER, S.C. and SNIDER, R.M. (1986) Amitriptyline produces supersensitivity to the hypothermic effects of nicotine. Presented at the Annual Meeting of the American College of Neuropsychopharmacology, Washington D.C., December 8-12, 1986.

DILSAVER, S.C. and SNIDER, R.M. (in press) Amitriptyline produces dose-dependent supersensitivity to oxotremorine. J. Clin. Psychopharmacol.

DILSAVER, S.C., SNIDER, R.M., and ALESSI, N.E. (in press a) Amitriptlyine produces supersensitivity of a central chlinergic mechanism. Biological Psychiatry.

DILSAVER, S.C., SNIDER, R.M., and ALESSI, N.E. (1986) Stress induces cholinergic system supersensitivity in rat. Biological Psychiatry 21: 1093-1096.

DILSAVER, S.C., GREDEN, J.F., and SNIDER, R.M. (in press b) Antidepressant withdrawal syndrome: Phenomenology and pathophysiology. Int Psychopharmacol.

DOMINO, E.F. and WILSON, A.E. (1973b) Effect of narcotic analgesic agonists and antagonists on rat brain acetylcholine. J. Pharmacol. Expt. Therap. 184: 18-32.

EHLERT, F.J., Roseke, W.F., and Yamamura, H.I. (1981a) Dopaminergic regulation of muscarinic receptor binding in the corpus stiatum. Proc. West Pharmacol. Soc. 24: 93-95.

EHLERT, F.J., et al. (1983) The nature of muscarinic binding. In: Handbook of Psychopharmacology, L.L. Iversen, S.D. Iversen, and S.N. Snyder (Eds.), Volume 17, Plenum, New York.

FRIEDMAN, M.J., JAFFE, J.H., and SHARPLESS, S.K. (1969) Central nervous system supersensitivity to pilocarpine after withdrawal of chronically administered scopolamine. J. Pharmacol. Expt. Therap. 167: 45-55.

GILLIN, J.C., SITARAM, N., and DUNCAN, W.C. (1979) Muscarinic supersensitivity: a possible model for the sleep disturbance of primary depression? Psychiat. Res. 1: 17-22. 
GOLDMAN, M.E. and ERICKSON, C.K. (1983) Effects of acute and chronic administration of antidepressant drugs in the central cholinergic nervous system: comparison with anticholinergic drugs. Neuropharmacol. 22: 1285-1222.

Got.nsteIN, A. (1984) Biostatistics, the MacMillan Company, New York, p. 00.

INNES, I.R. and NICKERSON, M. (1975) Atropine, scopolamine and related antimuscarinic drugs. In: The Pharmacological Basis of Therapeutics, ed. 5, L.S. Goodman and A. Gilman (Eds.), p 520, Macmillan, New York.

JAFFE, J. and SHARPLESS, J. (1968) Pharmacological desnervation suprersensitivty in the central nervous system. Research Public Assoc. Res. Nerv. Ment. Disease 46: $632-615$.

JHAMANDAS, K., SUTAR, M., and BELL, S. (1973) Modification of precipitated morphine withdrawal syndrome by drugs affecting cholinergic mechanisms. Eur. J. Pharmacol. 24: 296-305.

JHAMANDAS, K., TINSLEY, C., and PHILLIS, J.W. (1970) Effects of morphine and its antagonists on release of cerebral cortical acetylcholine. Nature 228: 176-177.

KUMBARACHI, M.N. and NASTUK, W.L. (1980) Effect of $\Delta{ }^{9}$-tetrahydrocannabinol on excitable membranes and neuromuscular transmission. Molec. Pharmacol. 17: 344-345.

LAYMAN, J.M. and MILTON, A.S. (1971) Some actions of $\Delta 1_{\text {-tetrahydrocannabinol and }}$ cannabinoids at cholinergic functions. Brit. J. Pharmacol. 41: 379P-380P.

LIPSCHULTZ, S. (1965) Theory and Problems in Probability, McGraw-Hill Book Company, New York.

LOMAX, P., FOSTER, R.F., and KIRKPATRICK, W.E. (1969) Cholinergic and adrenergic interactions in the thermoregulatory centers of the rat. Brain Res. 15: 431-438.

NOMURA, Y., KAJIYAMA, H., and SEGAWA, T. (1982a) Alteration in sensitivity to isoproterenol and acetylcholine in rat heart after repeated administration of isoproterenol. J. Pharmacol. Expt. Therap. 220: 441-445.

NOMURA, Y., KAJIYAMA, H., and OKAI, K. (1982b) Influence of repeated administration of dysmethylimipramine on B-adrenerglc and muscarinic cholinergic receptors and ${ }^{45} \mathrm{Ca}^{++}$binding to sarcoplasmic reticulum in the rat heart. J. Pharmacol. Expt. Therap. 223: 834-840.

NOMURA, Y., KAJIYAMA, A., and SEGAWA, T. (1983) Possible influence of noradrenalin on B-adrenergic and muscarinic receptors in rat heart, Effects of 6-hydroxydopamine, isoproterenol and desmethylimipramine. In: Molecular Pharmacology of Neurotransmitter Receptors, T. Segawa et al. (Eds), pp. 83-90, Raven Press, New York.

NORDBERG, A. and SUNDWALL, A. (1977) The effect of sodium pentobarbital on the apparent turnover of acetylcholine in different brain regions. Acta Physiological Scandinavica 99: 336-344.

NORDBERG, A. and WAHLSTROM, G. (1981) Changes in cholinergic function in the rat brain late in the abstinence after chronic barbital treatment. Drug and Alcohol Dependence 7: 51-61. 
ÖGREN, S.0., CARLSSON, S., and BARTFAI, T. (1985b) Serotonergic potentiation of muscarinic agonist evoked tremor and salivation in rat and mouse. Psychopharmacol. 86: $258-64$.

ÖGREN, S.0., NORNSTROM, Ö., DANIELSSON, E., PETERSON, L.L., and BERTFAI, T. (1985a) In vivo and in vitro studies on the potentiation of muscarinic receptor stimulation by alaproclate, a selective 5-HT uptake blocker. J. Neurol, Tranmsmission 11: 1-20.

OVERSTREET, D.H., KOZAR, M.P*, and LYNCH, G.S. (1973) Reduced hypothermic effects of cholinomimetic agents following chronic anticholinesterase treatment. Neuropharmacology 12: 1017-1032.

Physicians Desk Reference (PDR) (1986) pp. 1005-6.

RABIN, R.A., WOLFE, B.B., DIBNER, M.D., ZAHNISER, W.R., MELCHION, C. and MOLINOFF, P.B. (1980) Effects of ethanol administration and withdrawal on neurotransmitter receptor systems in 157 mice. J. Pharmacol. Exp. Therap. 213: 491-496.

REHAVI, M., RAMOT, 0., YAVETZ, B., and SOKOLOVSKY, M. (1980) Amitriptyline: long-term treatment elevates $\alpha$-adrenergic and muscarinic receptor binding in mouse brain. Brain Res. 194: 443-453.

RICHELSON, E, and DININETZ-ROMERO, S. (1977) Blockade by psychotropic drugs of the muscarinic acetylcholine receptor in cultured nerve cells. Biol. Psychiatry 12: $771-785$.

SHUR, E.S., CHECKLEY, E., and DELGADO, I. (1983) Failure of mianserin to affect autonomic function in the pupils of depressed patients. Acta Psychiatr. Scand. 67: $50-55$.

SIEGEL, S. (1956) Nonparametric Statistics, McGraw-Hill Book Company, New York.

SITARAM, N., MOORE, A.M., and GILLIN, J.C. (1979) Scopolamine-induced muscarinic supersensitivity in normal man: changes in sleep. Psychiat. Res, 1: 9-16.

SMITH, T.L. (1983) Influence of chronic ethanol consumption of muscarinic cholinergic receptors and their linkage to phospholipid metabolism in mouse synaptosomes. Neuropharmacology 22: 661-663.

SNYDER, S.H. and YAMAMURA, H.I. (1977) Antidepressants and the muscarinic acetylcholine receptor. Arch. Gen. Psychiatry 34: 236-239.

SZABADI, P., BASZNER, P., and BRADSHAW, C.M. (1980) The peripheral anticholinergic activity of tricyclic antidepressants. comparison of amitriptyline and desipramine in human volunteers. Br. J. Psychiatry 137: 433-439.

TABAKOFF, B, MUROZ-MARCUS, M., FIELDS, J.Z. (1979) Chronic ethanol feeding produces an increase in muscarinic cholinergic receptors in mouse brain. Life Sciences 25: 2173-2180.

TOCCO-BRADLEY, R., KLUGER, M.J., and KAUFFMAN, C.A. (1985) Effect of age on fever and acute phase response to endotoxin and salmonella typemurium. Infect. Immun. 47: $106-11$.

VIZI, E.S., HARSING, G, and LSILLA, G. (1981) Evidence of the modulatory role of serotonin in acetylcholine release from striatal interneurons. Brain Res. 212: 89-99. 
WAHLSTROM, G. (1978) Estimation of brain sensitivity to the convulsive effects of choline and changes induced by chronic barbital treatments in the rat. Eur. J. Pharmacol. 51: 219-227.

WAHLSTROM, G. and NORDBERG, A. (1979) Sensitivity to an active synaptosomal uptake of choline in the abstinence after chronic barbital treatments. Acta Physiol. Scandinavica suppl 473: $65-203$.

WAHLSTROM, G. and EKWALL, T. (1976) Tolerance to hexobarbital and supersensitivity to pilocarpine after chronic barbital treatments in the rat. European J. Pharmacol. 38: $123-129$.

WESTFALL, T.C. (1973) Effect of acetylcholine on the release of [ $\left.{ }^{3} \mathrm{H}\right]$ norepinephrine by nicotine and potassium chloride from rat brain slices. In: Frontiers in Gatecholamine Research, E. Usdin and S.H. Snyder (Eds.), pp. 617-618, Pergamon Press.

WISE, B.C. and SHOJI, KOO, J.F. (1980) Decrease or increase in cardiac muscarinic cholinergic receptor number in rats treated with methacholine or atropine. Biochem. Biophys. Res. Comm. 92: 1132-1142.

YAMADA, S., IOGAI, M., OKUDAIRA, H., and HAYASHI, E. (1983) Regional adaptation of muscarinic receptors and choline uptake in brain following repeated administration of diisopropylfluorophosphonate and atropine. Brain Res. 268: 315-320.

YOSHIMURA, H., FUJIWARA, M., and UEKI, S. (1974) Biochemical correlates in mouse-killing behavior of the rat: brain acetylcholine and acetylcholinesterase after administration of $\Delta^{9}$-tetrahydrocannabinol. Brain Res. 81: 567-570.

Inquiries and reprint requests should be addressed to:

Dr. Steven C. Dilsaver

Mental Health Research Institute

Department of Psychiatry

Univ. of Michigan

205 Washtenaw Place

Ann Arbor, MI 48109-0010

U.S.A. 